УДК 666.972.16

\title{
ПІДВИЩЕННЯ АДГЕЗІЙНОЇ МІЦНОСТІ НАЛИВНИХ ПІДЛОГ
}

К-т техн. наук І. Е. Казімагомедов, аспір. С. Ю. Шептун

ПОВЫШЕНИЕ АДГЕЗИОННОЙ ПРОЧНОСТИ НАЛИВНЫХ ПОЛОВ

К-т техн. наук И. Э. Казимагомедов, аспир. С. Ю. Шептун

INCREASE ADHESIVE STRENGTH OF SELF-LEVELING FLOORS

Cand. of techn. sciences I.Kazimagomedov, postgrad. S.Y.Sheptun

В роботі вивчається можливість застосування відходів виробництва для поліпшення адгезійних властивостей сухих будівельних сумішей. $B$ якості відходів виробництва 
розглядалися: илам від мокрої газоочистки виробнищтва феросиліцію, шлам водопом'якщення Харківської ТЕЦ - 5 і керамзитовий пилХарківського керамзитового заводу.

Ключові слова:суха будівельна суміш, наливна підлога, мікронаповнювач, шлам, керамзитовий пил, адгезія, відходи виробництва.

В работе изучается возможность применения отходов производства для улучшения адгезионных свойств сухих строительных смесей. В качестве отходов производства рассматривались: илам от мокрой газоочистки производства ферросиличия, шлам водоумягченияХарьковской ТЭЦ - 5 и керамзитовая пыль Харьковского керамзитового завода.

Ключевые слова: сухая строительная смесь, наливной пол,микронаполнитель, илам, керамзитовая пыль, адгезия, отходы производства.

For many years, there is a question about the possibility of using industrial wastes. After many years of industrial enterprises, large volumes of waste products that are hardly used. To improve the economic efficiency of dry mixes and reduce anthropogenic impact on the environment, we decided as a filler to use the following waste products: sludge from wet gas cleaning ferrosilicon production, sludge water softening ofthermoelectric power station and expanded clay dust. As a result, it was revealed the positive and negative effects on the properties of microfillers dry construction mixtures. This article presents data on adhesive strength by adding three types of microfillers, which have been mentioned above.

Keywords:dry mortar, self-leveling floor, adhesion, waste production

\section{Вступление}

Производство сухих смесей считается приоритетным направлением промышленности строительных материалов. Применение сухих строительных смесей (ССC) заводского изготовления позволяет удовлетворить все более возростающие требования к качеству и экономичности строительства [1].

Рынок ССС постоянно развивается, предлагая потребителям все новые виды продукции. Однако потенциал его развития раскрыт не полностью, особенно это касается смесей для самовыравнивающихся покрытий.

Пол гражданских и промышленных зданий - это основной элемент конструкций и интерьера здания, который воспринимает эксплуатационные воздействия, на котором осуществляется весь производственный процесс и жизнедеятельность людей.

В наше время в конструкции пола могут входить: основание, подстилающий слой [2], звукоизоляция, теплоизоляция, стяжка, гидроизоляция, грунтовка, покрытие [3].

Монолитные бесшовные покрытия в большинстве случаев применяются в промышленных, сельскохозяйственных и общественных (спортивных, учебных и др.) зданиях. В производственных помещениях часто применяются монолитные покрытия из композиций на цементных вяжущих. Такие покрытия имеютхорошие эксплуатационные характеристиками, и сравнительно невысокую стоимость.

Полы зданий должны обладать необходимой прочностью, износостойкостью, упругостью, высокой адгезионной прочностью, гладкостью, невысокой теплопроводностью и легко очищаться от загрязнений.

\section{Анализ последних исследований}

На сегодняшний день, еще нет общепринятой теории, которая полностью объясняла процесс адгезии. В связи с разнообразностью явлений, которые происходят на разных этапах процесса сцепления материаллов, создание общей теории процессов адгезии значительно усложняются [4].

Одной из первых теорий, которая была предложена для объяснения процесса склеивания, была гипотеза Мак-Бена [5], которая рассматривает этот процесс как механическое “заклинивание"клеящего вещества в порах материала. Однако, предположения Мак-Бена были 
опровергнуты[6]. Позже появились мнения про так называемую "специфическую" адгезию. Под адгезией принято понимать сцепление, которое возникает между двумя соприкасающимися материалами. При случае клеевых соединений адгезия - это сцепление между клеящим веществом и поверхностью, которая склеивается. При рассмотрении адгезионных явлений необходимо учитывать и когезию сцепление в средине склеенных материалов. В настоящий момент наибольшее значение набирают адсорбционная, электрическая, диффузионная и химическая теория адгезии.

На данный момент известен ряд способов улучшения клеящей способности цементного камня. Один изних основан на концепции, которая рассматривает цементный камень как микробетон [7]. В соответствии с этой концепцией рационально повышать дисперсность цементного клея, обеспечивая его полную гидратацию, через помол. Зерна цемента крупностью больше 40 мкм, которые практически не гидратируются, рационально заменить наполнителями. На этой концепции основываются технологии сухого и мокрого помола цемента вместе с песком и другими наполнителями, в результате чего получается коллоидный цементный клей [8]. Помол цемента не получил распространения в связи с высокой энергоемкостью, несовершенной конструкцией помольных агрегатов и быстрой потерей активности.

Значительное развитие получили исследования по активации цементного вяжущего, а также смеси цемента с наполнителями [7]. К наполнителям относят порошкоподобныеили материалы, которые применяют для экономии вяжущего и регулирования физико-технических свойств композиционных материалов, в том числе строительных.

Зола уноса активно влияет на всех стадиях гидратации и структурообразования цементных систем, формирование структуры композиционных строительных материалов, то есть последовательного перехода от коагуляционной структуры к образованию пространственного кристаллического каркаса. Введение золы-уноса в растворные смеси в качестве активного наполнителя является известным технологическим приемом, который направлен на снижение расхода цемента и извести. Так помол золы до удельной поверхности $390 \quad \mathrm{~m}^{2} / \kappa \Gamma$ позволяет увеличить прочность сцепления раствора с основой в возрасте 7 суток на $14 . .26 \%$, в возрасте 28 суток - на $13 \ldots 18 \%$ [9].

Введение в составы воздухововлекающей и полимерной добавки Tyloseoбеспечивает необходимую водоудерживающую способность растворной смеси и снижает толщину необходимого клеевого шара, что позитивно влияет на величину адгезии. Увеличение содержания воздухововлекающей добавки от 0 до $0,025 \%$ от массы цемента увеличивает адгезионную прочность на $30 \ldots 45 \%$, при последующем увеличении содержания добавки адгезионная прочность несколько снижается. Увеличение содержания водоудерживающей добавки Tylosa от 0 до $0,15 \%$ приводит к повышению адгезионной прочности на $25 . .55 \%$, дальнейшее повышение содержания этой добавки не приводит к значительному повышению адгези[10].

Введение карбонатного наполнителя увеличивает, как и зольный наполнитель, объем гидратных новообразований, что также позитивно влияет не величину адгезионной прочности растворов. Увеличение содержания карбонатной пыли до $15 \%$ от массы цемента приводит к увеличению адгезионной прочности на $16 . .33 \%$ во все сроки твердения [10].

Проанализировав литературные источники, мы пришли к выводу, что влияние шлама от мокрых газоочисток производства ферросилиция и керамзитовой пыли на адгезионные свойства наливных покрытий недостаточно изучено.

\section{Цели и задачи исследования}

Целью нашего исследования является увеличение адгезионной прочности раствора сухой строительной смеси к бетону за счет использования отходов производства. Использование отходов производства таких, как шлам от мокрых газоочисток 
производства ферросилиция и керамзитовой пыли, должно не только удешевить себестоимость смесей, но и способствовать решению экологических проблем.

\section{Основная часть исследования}

Изучив множество литературных источников, мы пришли к выводу что для улучшения физико-технических свойств сухих строительных смесей можно использовать тонкодисперсные наполнители в частности: шлам от мокрых газоочисток производства ферросилиция Стахановского завода ферросплавов города Стаханов Луганской обл.; керамзитовую пыль, получаемуюпри обжиге керамзитового гравия; шлам водоумягчения ТЭЦ - 5 .

Шлам мокрой газоочистки Стахановского завода образуется,при выплавки ферросилиция, во время очистки исходящего ферросплавного газа от пыли по технологии мокрой газоочистки.
Использование шлама в строительных материалах, будет способствовать повышению экономической и экологической эффективности как металлургического производства так и строительства.

Однако, нельзя использовать шлам прямо из отвалов. На протяжении многих лет складирования, он, под воздействием атмосферных явлений, превратился в цельную глыбу. Поэтому его необходимо перед использованием измельчить. Измельчение шлама проводился на дезинтеграторе после предварительной его сушки в электрическом сушильном шкафу. В результате измельчения был получен микронаполнитель со средней плотностью $180-250$ кг $/ \mathrm{M}^{3}$ и удельной поверхностью $15000-25000 \mathrm{~cm}^{2} / \Gamma$ [11]. Химический состав шлама от мокрых газоочисток производства ферросилиция представлен в таблице 1.

Таблица 1

Химический состав шлама

\begin{tabular}{|l|c|c|c|c|c|c|c|c|c|c|c|}
\hline \multirow{2}{*}{$\begin{array}{l}\text { Наименование } \\
\text { шлама }\end{array}$} & \multicolumn{7}{|c|}{ Содержание компонентов, \% } \\
\cline { 2 - 10 } & $\mathrm{SiO}_{2}$ & $\mathrm{Fe}_{2} \mathrm{O}_{3}$ & $\mathrm{~A}_{2} \mathrm{O}$ & $\mathrm{CaO}$ & $\mathrm{MgO}$ & $\mathrm{K}_{2} \mathrm{O}$ & $\mathrm{Na}_{2} \mathrm{O}$ & $\mathrm{TiO}$ & $\mathrm{P}_{2} \mathrm{O}_{5}$ & $\mathrm{MnO}$ & п.п.п. \\
\hline $\begin{array}{l}\text { Более 20-ти летней } \\
\text { давности } \\
\text { послепроизводства }\end{array}$ & 81,3 & 3,6 & 3,5 & 1,2 & 1 & 0,9 & 0,65 & 0,1 & 0,03 & 0,01 & 7,71 \\
\hline
\end{tabular}

Керамзитовая пыль - отход керамзитового производства, получаемый при обжиге керамзитового гравия. Представляет собой мелкодисперсный коричневого цвета кремнеземсодержащий материал, обладающий свойствами активных минеральных добавок, плотностью 600-700 кг $/ \mathrm{M}^{3}$ и удельной поверхностью $2500-4000$ $\mathrm{cm}^{2} /$. . Химический состав керамзитовой пыли представлен в таблице 2.

Таблица 2

Химический состав керамзитовой пыли

\begin{tabular}{|c|c|c|c|c|c|c|c|c|c|c|c|c|}
\hline \multirow[b]{2}{*}{$\begin{array}{l}\text { Наименнование } \\
\text { материала }\end{array}$} & \multicolumn{12}{|c|}{ Содержание компонентов, \% } \\
\hline & อ & 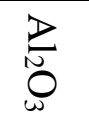 & 孞 & Оి & $a_{0}^{3}$ & 不 & تై & $\tilde{\omega}$ & 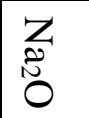 & No & 3 & $\stackrel{\boxminus}{\dot{\varphi}}$ \\
\hline Керамзитовая пыль & 61,65 & 16,2 & 7,8 & 1,76 & 3,11 & 2,46 & 1,19 & 1,16 & 0,94 & 0,31 & 0,28 & 3,14 \\
\hline
\end{tabular}

Минеральный модификатор в виде шлама водоумягчения Харьковской ТЭЦ -5 благодаря своей дисперсности (более 2870 см2/г) и своеобразию структуры частиц позволяет значительно улучшить эффективность работы пластификатора, модифицированной целлюлозы редиспергируемогосополимерного порошка. Химический состав шлама водоумягчения ТЭЦ - 5 следующий: $\mathrm{CaCO}_{3}$ $58,2 \%$,портландита - 33,4 \%, остальное примеси. Введение шлама водоумягчения Харьковской ТЭЦ в систему позволяет изменять комплекс еe структурно- 
механических свойств: регулировать вязкость, снижать усадочные явления и замедлять схватывание.

Составы сухих строительных смесей и их характеристики на которых проводилась оценка влияниясочетаний шлама от мокрых газоочисток производства ферросилиция, керамзитовой пыли и шлама водоумягчения Харьковской ТЭЦ -5 на адгезию представлены в таблице 3.

Таблица 3

Адгезионная прочность разработанных составов

\begin{tabular}{|c|c|c|c|c|c|}
\hline Наименование материала & \multicolumn{5}{|c|}{ Содержание компонентов } \\
\hline Цемент Пц-500, мас. ч. & 33 & 33 & 33 & 33 & 33 \\
\hline Песок, мас. ч. & 47 & 47 & 47 & 47 & 47 \\
\hline Пластиф. Melflux, мaс. ч. & 0,5 & 0,5 & 0,5 & 0,5 & 0,5 \\
\hline Мод целBermocoll, мас. ч. & 0,01 & 0,01 & 0,01 & 0,01 & 0,01 \\
\hline Редиспергир. порошок мас. ч. & 1 & 1 & 1 & 1 & 1 \\
\hline Шлам 25 лет, в \%, от цемента & $15 \%$ & $15 \%$ & $15 \%$ & $15 \%$ & $15 \%$ \\
\hline Керамзит, в \%, от цемента & - & - & - & $5 \%$ & $10 \%$ \\
\hline Шлам ТЭЦ-5, в \%, от цемента & - & $5 \%$ & $10 \%$ & - & - \\
\hline Вода, В/Ц & 0,7 & 0,7 & 0,7 & 0,7 & 0,7 \\
\hline \multicolumn{6}{|c|}{ Прочность сцепления с бетонным основанием } \\
\hline 3 дн $\left(к Г с / \mathrm{cm}^{2}\right)$ & 5 & 5 & 3 & 6 & 6 \\
\hline 7дн (кге/см²) & 8 & 5 & 2 & 4,5 & 8 \\
\hline $14 д н\left(к г е / \mathrm{cm}^{2}\right)$ & 5 & 5 & 3 & 6 & 6 \\
\hline $28 д н\left(к г \mathrm{c} / \mathrm{cm}^{2}\right)$ & 10,5 & 10,5 & 9 & 14 & 13 \\
\hline
\end{tabular}

Из полученных результатов видно, позитивное влияние совместного добавления шлама и керамзитовой пыли. Однако совместная работа шлама от мокрых газоочисток производства ферросилиция и шлама уноса ТЭЦ оказалась менее пригодной.

\section{Выводы}

Таким

образом,

совместное применение минеральных наполнителей, инертных по отношению к воде, с суперпластификатором в цементных растворах и бетонах открывает широкие возможности получения композиционных материалов требуемой прочности при рациональном расходе цемента и существенной его экономии.

\section{Список використаних джерел}

1. Рекитар Я. А. Долговременные тенденции развития производства строительных материалов и инвестиционная политика в этой области / Я. А. Рекитар // Строительные материалы, оборудование, технологии XXI века. - 2001 г. - №7.

2. Стасенко Ю. М. Современные напольные покрытия / Ю. М. Стасенко // Строительные материалы, оборудование технологии XXI века. - 2004. - №1. - с. 20-21.

3. Голенковская В. А. Устройство наливных полов с применением сухих строительных смесей / В.А. Голенковская // Строительные материалы. - 2000. - №1. - С. 1617.

4. Карданов А.В. Синтетическиеклеи / А.В. Карданов // Москва: Химия, 1968. - 584.

5. McBain J.W., AdhesiveResearchCommitteeReports, 1, 2, 3(H.M. Stationery Office, London, 1922, 1926, 1932).

6. Дерягин Б.В. Адгезия / Б.В. Дерягин , Н.А.Кротова //Изд. АН СССР, 1949.- 12 с.

7. Соломатов В.И. Пути активизации наполнителей композиционных строительных материалов / Соломатов В.И., Дворкин Л.И.,Чудновский С. М. // Изв. вузов: Строительство и архитектура. $-1987 .-\mathrm{N} 1-$ С. $60-63$. 
8.Соломатов В. И. Химическое сопротивление композиционных строительных материалов / В. И. Соломатов //Москва:Стройиздат, 1987. - 264 с.

9. Медяник Ю. В. Смешанное вяжущее с наполнителем из шлама водоумягчения для сухих штукатурных смесей: дис. на соиск. учен. степ. канд. техн. наук: спец. 05.23.05/ Ю. В. Медяник // Казань, 2003 г.

10. Дворкін Л. Й. Модифіковані золовмісні сухі будівельні суміші для мурувальних і клейових розчинів / Л. Й. Дворкін, О. Л. Дворкін, Ю. В. Гарніцький, І. М. Риженко // Рівне: НУВГП, 2013. - 219 с.

11. Казимагомедов И. Э. Сухие строительные смеси, наполненные шламами мокрых газоочисток производства ферросилиция / И. Э. Казимагомедов, С. Ю. Шептун. // Теория и практика повышения эффективности строительных материалов: материалы IX Международной конференции молодых учёных. - Пенза: ПГУАС, 2014. - 176 с.

Рецензент д-р техн. наук, професор О.Г. Вандаловський

\footnotetext{
Шептун Сергей Юрьевич асп. кафедры строительных материалов и изделий Харьковского национального университета строительства и архитектуры. Tел. 94-38-32. E-mail: zoooms@ ukr. net

Казимагомедов Ибрагим Эмирчубанович канд. техн. наук,кефедрыстроительных материалов и изделий Харьковского национального университета строительства и архитектуры. Тел. 706-20-73.

Sheptun Sergey Yurievich,PostgraduateattheDepartmentof building materials and products Kharkiv National University of Civil Engineering and Architecture.Tel.94-38-32E-mail: zoooms@ukr.net

KazimagomedovIbrahim,CandidateofEngineeringSciences,AssociateProfessorattheDepartmentof building materials and products Kharkiv National University of Civil Engineering and Architecture.Tel. 706-20-73.
} 